FOLIA POMERANAE UNIVERSITATIS TECHNOLOGIAE STETINENSIS

Folia Pomer. Univ. Technol. Stetin., Agric., Aliment., Pisc., Zootech. 2021, 358(57)1, 41-52

Review article

Received 17 Aug 2020

Revised 8 Jan 2021

Julia WALSKA(i)

Accepted 15 Jun 2021

\title{
PROPOSED MONITORING OF LESSER MOUSE-DEER Tragulus kanchil
}

Faculty of Animal Breeding, Bioengineering and Conservation, Warsaw University of Life Sciences, Warszawa, Poland

\begin{abstract}
The lesser mouse-deer Tragulus kanchil Raffles, 1821 is a small, herbivorous mammal inhabiting regions of Southeast Asia. Unlike other species belonging to the same genus, the lesser mouse-deer is not critically endangered, however the biology and population size of the species are not studied well enough. So far no methods of monitoring of the species condition have been developed and for this reason, an exemplary protocol of the monitoring of lesser mouse-deer is presented in the paper below. The main goal of such studies is to estimate the population size and density, as well as to assess the quality of the habitat occupied by the animals. In order to evaluate the species condition, population and habitat indicators were developed. The methodology of studies is mostly based on counting specimens in transects, together with assessing the habitat quality and availability of food supply. Supplementary methods were suggested, such as genetic testing and using camera traps. Conducting such research is believed to aid in better understanding of the environmental requirements and possible threats, which may have a significant impact on the lesser mouse-deer population. In the future, methods suggested in this paper can be improved or extended, so that the matter is examined as comprehensively as possible and suitable conservation measures can be applied.
\end{abstract}

Key words: lesser mouse-deer, Tragulus kanchil, monitoring, conservation.

\section{INTRODUCTION}

The lesser mouse-deer (also known as lesser Malay chevrotain, lesser oriental chevrotain or Tragulus kanchil) is a small ungulate, belonging to the family Tragulidae. Chevrotains are believed to be 'living fossils', as they are the oldest still existing species of ruminant (Grzimek 2003). It was classified as a 'least concern' (LC) species by the IUCN Red List of Threatened Species (Timmins and Duckworth 2015). Adult specimens measure $42-49 \mathrm{~cm}$ in total body length, 25-30 cm in height at the withers, and their body weight does not exceed 2 kilograms. Chevrotain's tail measures about 6-9 cm. Its coat is short, shiny and usually rusty brown in colour, with distinctive white markings on chest and neck, and lighter coloured abdomen. Skin on chevrotain's neck and hindquarters is especially thick and durable, which protects the animal against the attacks of the predators. Four-fingered limbs are very slim and delicate, however the body is more massive. Kanchil does not grow antlers, its head is wedge-shaped, with big eyes equipped with tapetum lucidum, and small earlobes. Males fight each

Corresponding author: Julia Walska, Faculty of Animal Breeding, Bioengineering and Conservation, Warsaw University of Life Sciences - SGGW, Jana Ciszewskiego 8, 02-786 Warszawa, Poland, e-mail: juliawalska2@gmail.com 
other using elongated upper canines, while in females canines are much shorter. Males also have a scent gland located on the chin, which they use to mark territory and during mating season (Grzimek 2003).

Tragulus kanchil presents mostly crepuscular or nocturnal behavioural pattern (its activity peak is observed between 5 and 7 A.M., up to 10. A.M., and between 3 and 6 P.M.). During daytime the animal spends most of its time hidden in dense vegetation, while after twilight it can be seen in open areas. Data obtained using GPS transmitters or camera traps shows, that kanchils move an average of $550 \mathrm{~m}$ a day. Chevrotains are territorial, both males' and females' territories cover the area of approximately 5 hectares. Territories occupied by females do not overlap one another, however they overlap with those occupied by males. These animals usually live solitarily or in pairs (specimens living in pairs make less than $5 \%$ of all observed cases). Kanchils communicate with one another through scent signals (urine, feces, secretion from scent gland on the male's chin) and through vocalization (Grzimek 2003). When alarmed, the animal freezes, bleats quietly or stomps with its hind hooves with frequency of 4-7 hits per second. The aim of such behaviour is to scare away predators or to warn other chevrotains.

The lesser mouse-deer is a herbivore, feeding mostly on fallen fruit (typically about $1-5 \mathrm{~g}$ in mass), for example fruit of fig-trees, young plant shoots, seeds, leaves and fungi. There were rare cases in which kanchils were observed to also feed on invertebrates and small vertebrates (Heydon and Bulloh 1997).

Chevrotains can breed throughout the year. During mating season males fight with each other for access to females. Kanchils are among the fastest reproducing species of ungulates. Female's oestrus cycle lasts for about 14 days. Gestation lasts approximately 132-145 days, usually just one young is born (Jinaka 1995), in very rare cases twin pregnancy occurs. The fawn weights $120-190 \mathrm{~g}$ and is able to stand on its own after 30 minutes. The female can start another oestrus, mate and become pregnant only two hours after giving birth. Lactation usually last for about 10-13 weeks. Young chevrotain spends most of the time hidden in dense vegetation and is fed by its mother twice a day. The female most often takes a distinctive position with one hind leg up while feeding. Chevrotain's milk is rich in fat $(26,8 \%)$. The young reaches the size of an adult after five months. Kanchils reach sexual maturity very fast - females at age of approximately 125 days and males at 166 days (Timmins and Duckworth 2015).

The lesser mouse-deer inhabits tropical forests of Southeast Asia. It prefers lowlands and plains, and usually occupy habitats with dense vegetation, that are not degraded by human activity. The population size is correlated with the number of fruit tree, especially from genus Ficus (Heydon and Bulloh 1997). These animals can often be spotted near watercourses, because alarmed kanchils sometimes escape by going into the water. The animals can also often be found near big rocks or fallen tree trunks (Nowak and Paradiso 1983).

Tragulus kanchil inhabits regions of south Asia: Myanmar, Brunei, Cambodia, China (province Yunnan), Indonesia, Laos, Malaysia, Singapore, Thailand and Vietnam. Size of the population in these regions are not well studied, however according to Payne et al. (1985) chevrotain inhabits (or inhabited, according to other reports) at least Borneo in larger numbers. 
The main goal of the monitoring should be to give insight into changes impacting the population in regions of Asia, that are currently known to be inhabited by kanchil. It should also allow researchers to evaluate tendencies in the development of the already known populations. Lesser mouse-deer is not a very rare species, however because of its secretive behaviour and relatively poor understanding of its biology, the monitoring of the species should be carried out regularly, so that any detrimental changes can be noticed and it is possible to react to them efficiently.

\section{MATERIAL AND METHODS}

The method of population monitoring described in this paper is based on estimating the number of specimen observed in transects designated in monitoring locations. Because of its small silhouette and nocturnal or crepuscular behaviour, it is possible to confuse Tragulus kanchil with another species of mouse-deer. Such mistakes may hinder the research and make its results unreliable. The recommended solution is to additionally conduct genetic monitoring, based on genetic testing of collected feces samples. Using such method might aid in correcting or complement data collected through direct counting animals in transects. Another additional method is based on the use of camera traps.

The monitoring includes also the evaluation of the status of the natural habitat in monitoring locations. Such evaluation consists of analysis of the type and quality of the habitat, together with availability of food supply.

Hopefully, as more of the environmental factors that impact kanchil's population and species' preferences, are studied, it will be possible in the future to improve monitoring methods and form the most accurate ways of habitat evaluation.

In order to determine, whether the population is in good condition, two main factors need to be considered - the total number of specimens in studied area and number of mothers with young. Habitat's state indicators are type of habitat and quality of food supply (Table 1).

Table 1. Parameters used in lesser mouse-deer monitoring

\begin{tabular}{lll}
\hline \multicolumn{1}{c}{ Parameter } & \multicolumn{1}{c}{ Measure } & \multicolumn{1}{c}{ Description } \\
\hline Population density & specimens $/ \mathrm{km}^{2}$ & $\begin{array}{l}\text { Mean density of specimens calculated from number of animals } \\
\text { spotted in transects (calculation is based on sum of observed } \\
\text { kanchils and total studied area) }\end{array}$ \\
Reproduction & descriptive parameter & $\begin{array}{l}\text { Researcher's subjective evaluation of presence of mothers } \\
\text { with young }\end{array}$ \\
\hline Type of habitat & descriptive parameter & $\begin{array}{l}\text { Researcher's description of the type of habitat and level of its } \\
\text { degradation }\end{array}$ \\
Food supply & descriptive parameter & $\begin{array}{l}\text { Researcher's subjective evaluation of availability and quality } \\
\text { of food supply within the range of studied transect (with trees } \\
\text { from genus Ficus being the most important factor) }\end{array}$
\end{tabular}


According to Heydon and Bulloh (1997), population density of lesser mouse-deer in primeval forest can be estimated at 21-49 specimens per square kilometre, while in degraded habitats that undergo significant levels of deforestation - 10-15 specimens per square kilometre. Kanchils reproduce throughout the year and females give birth to just one young at the time. Because of low fertility rate, the number of females that participate in reproduction gives crucial information about the current state of the population. The season of the year does not have impact on reproduction, because of the conditions of the climatic zone inhabited by kanchils, however in less favourable environment the species' reproductive rate could be negatively impacted, due to limited access to potential mates and food supply. In accordance with these facts and assumptions, the following protocol of evaluation is suggested (Table 2 and 3).

Table 2. Evaluation of population parameters

\begin{tabular}{lccc}
\hline Parameter / Evaluation & FV (favourable) & $\begin{array}{c}\text { U1 (unfavourable } \\
\text { inadequate) }\end{array}$ & U2 (unfavourable bad) \\
\hline Population density & $\begin{array}{c}\text { Population } \\
\mathrm{km}^{2}\end{array}$ & $\begin{array}{c}10-20 \text { specimens } / \\
\mathrm{km}^{2}\end{array}$ & $<10$ specimens $/ \mathrm{km}^{2}$ \\
\hline Reproduction & $\begin{array}{c}\text { numerous mothers } \\
\text { with young }\end{array}$ & $\begin{array}{c}\text { few mothers with } \\
\text { young }\end{array}$ & lack of mothers with young \\
\hline
\end{tabular}

Table 3. Evaluation of habitat parameters

\begin{tabular}{|c|c|c|c|}
\hline Parameter / Evaluation & FV (favourable) & $\begin{array}{l}\text { U1 (unfavourable } \\
\text { inadequate) }\end{array}$ & U2 (unfavourable bad) \\
\hline \multicolumn{4}{|c|}{ Habitat } \\
\hline Type of habitat & primeval forest & $\begin{array}{l}\text { old secondary forest } \\
\text { (>20 years) }\end{array}$ & $\begin{array}{l}\text { deforested areas / young se- } \\
\text { conddary forest ( }<20 \text { years) }\end{array}$ \\
\hline \multicolumn{4}{|c|}{ Food supply } \\
\hline $\begin{array}{l}\text { Presence of fruit trees / } \\
\text { shrubs and fallen fruit }\end{array}$ & $\begin{array}{l}\text { numerous fruit trees / } \\
\text { shrubs and fallen fruit }\end{array}$ & $\begin{array}{l}\text { few fruit trees / shrubs } \\
\text { and fallen fruit }\end{array}$ & $\begin{array}{l}\text { lack or a very small number } \\
\text { of fruit trees / shrubs and fallen } \\
\text { fruit }\end{array}$ \\
\hline
\end{tabular}

\section{EVALUATION OF POPULATION CONDITION}

Each of the parameters is assessed with a specific number of points:

- for FV - 2 points,

- for U1 - 1 point,

- for U2 - 0 points.

Total evaluation of population parameters:

- FV $=4-3$ points,

- U1 = 2 points,

- U2 $=0-1$ points. 


\section{EVALUATION OF HABITAT CONDITION}

Each of the parameters is assessed with a specific number of points:

- For FV - 2 points,

- For U1 - 1 point,

- For U2 - 0 points.

Total evaluation of habitat parameters:

- FV $=4-3$ points,

- U1 $=2$ points,

$-\mathrm{U} 2=0-1$ point.

\section{PERSPECTIVES OF CONSERVATION}

This is an expert evaluation taking into account the status of population and habitat in monitoring location, current tendencies, information of known impacts and predicted threats (such as deforestation, increasing tourist activity, predation pressure).

FV - good or very good perspectives - when the population is large and not isolated, reproduction is uninterrupted, the habitat is not degraded and suits the species requirements, food supply is sufficient, there are no major impacts and threats. Population is believed to remain in at least good condition, or to improve due to applied conservation measures.

U1 - moderately good perspectives, condition of population or habitat may worsen due to lack of conservation measures, or there is risk of persistent unfavourable condition in the future.

U2 - bad perspectives, significant worsening of the condition of population and habitat is anticipated, or current bad condition is believed to remain unchanged.

\section{OVERALL ASSESSMENT}

Overall assessment is the final assessment, that includes the evaluations of parameters mentioned above: condition of the population, condition of the habitat and perspectives of conservation. Each of the partial assessments is assigned a point value, according to the following key: FV - 2 points, U1 - 1 point, U2 - 0 points.

Total sum of points corresponds with the following final evaluations:

$-5-6$ points $-\mathrm{FV}$,

- 3-4 points - U1,

$-1-2$ points - U2.

If population density was given U1 index, the final evaluation cannot equal FV and should be lowered.

\section{DESCRIPTION OF THE PROCEDURE FOR THE MONITORING OF POPULATION AND HABITAT}

\section{Selection of monitoring locations}

The monitoring locations are square areas measuring ten by ten kilometres, that make up the "grid" covering the entire known range inhabited by lesser mouse-deer. In such square, the person who carries out the monitoring should demarcate transects (a minimum of five). The area covered by the transect may vary, depending on terrain conditions, such 
as vegetation density, that might obstruct the passage. However, each transect should be at least 500 meters long (dimensions and localisation of each transect should be determined using a GPS transmitter and included in the report paper and calculations). Transects inside each monitoring locations should be distributed evenly, so that the distribution of the population is presented as reliably as possible.

\section{METHOD OF PERFORMING STUDIES}

\section{Population condition indicators}

\section{a. Population density and size}

The main method of studying the size of population is counting specimens observed in designated transects. Observing chevrotains in field is problematic, because of the species' small body size, secretive behaviour and periods of activity falling in the early morning, late evening and night hours. Conducting monitoring studies requires the involvement of many people, to collect necessary data from as large an area as possible at the same time, which should prevent the same specimens from being counted twice. The optimal period for carrying out monitoring procedures would be hours, when the animals are the most active, which may adversely affect the research results, due to the limited visibility. For this reason, flashlights or night vision devices are essential equipment during studies conducted at night. Due to the possible inaccuracy of the research results, it is also recommended to use supplementary methods.

\section{b. Presence of mothers with young}

This method consists of researcher's subjective assessment supported by previous experiences and knowledge. It is based on descriptive evaluation, however recording encountered cases of mothers with young is suggested for future development of the method.

\section{c. Other parameters that can be additionally used in the assessment of the population condition}

Fallen specimens - due to small body size and lush vegetation found in the natural habitat of chevrotain, it may be difficult to find most fallen animals, however such discovery might give researchers important data, for example, on the cause of Death.

Age and gender structure of the population - percentage of adult and juvenile specimens in population, together with percentage of males and females.

\section{d. Supplementary methods Genetic monitoring}

Genetic monitoring should be based on testing feces samples. Collecting of the test material may be done additionally while observing kanchils in transects. Samples are placed in described test tubes in $70 \%$ ethanol. Further analysis should include species identification 
(to exclude samples from e.g. other species of chevrotains) and individual differentiation of specimens by using microsatellite sequences (STRs). Due to such analyses, estimation of the minimum number of Malay chevrotains in the studied area is possible. Moreover, genetic testing aids in determining the degree of isolation of the population and the direction of the gene flow, as well the gender structure of the population.

\section{Camera traps}

For the purpose of supplementing the information and better understanding of the biology of the species, camera traps can be used. Such a solution allows to conduct observations in noninvasive way, without the risk of scaring the animals away.

\section{Habitat condition indicators}

The required elements should be noted on the report sheet. The indicators describing the condition of the habitat should be determined once a year, during the observations in transects.

\section{Time and frequency of studies}

The monitoring studies of lesser mouse-deer population and habitat status in the areas should be conducted annually, or semiannually in cases where there is indication of evidently bad or worsening condition of population. The choice of months in which the studies will be carried out is not important due to the climatic zone. However, it is not advisable to conduct monitoring activities during the summer monsoon in areas affected by heavy rainfall, as they may significantly hinder observation. Report sheet should be sent at the end of each halfyear to the coordinated body.

\section{Equipment used in studies}

During the studies there is specific equipment required:

- clothing and footwear suitable for the conditions,

- GPS transmitter,

- flashlights or spotlights, night vision devices,

- stationery and report forms (Tables 4-8),

- tools needed for moving in terrain with rich vegetation,

- camera,

- binoculars,

- topographical map at scale 1:10000.

In case of supplementary methods (genetic testing), necessary equipment consists of test tubes, preservation solution $(70 \%$ ethanol), as well as necessary financial resources for performing the analyses. Camera traps can also be used additionally. 
Table 4. An example of a filled-in habitat observation sheet - monitored location

\begin{tabular}{|c|c|}
\hline \multicolumn{2}{|r|}{ Report sheet for the monitored location } \\
\hline Coordinator & $\begin{array}{l}\text { first and last name of the person carrying out the studies: } \\
\text { Jan Kowalski, Anna Nowak }\end{array}$ \\
\hline Date of inspection & 01-04.06.2020, 05-08.12.2020 \\
\hline Weather conditions & brief information about temperature, precipitation etc. \\
\hline $\begin{array}{l}\text { Name of the monitored } \\
\text { species }\end{array}$ & lesser mouse-deer (Tragulus kanchil, Raffles 1821) \\
\hline Name of the location & Danum Valley \\
\hline Type of the location & research \\
\hline $\begin{array}{l}\text { Protected areas where the } \\
\text { monitored location is situated }\end{array}$ & Danum Valley Conservation Area, Sabah, Malaysia \\
\hline Geographical coordinates & $\begin{array}{l}\text { geographical coordinates of the central point of location: } \\
\mathrm{N} 05^{\circ} 00^{\prime} 58^{\prime \prime} \mathrm{E} 117^{\circ} 45^{\prime} 09^{\prime}\end{array}$ \\
\hline Elevation a.s.l. & 500-903 m \\
\hline Location area & $\begin{array}{l}\text { in ha, a, } m^{2} \text { or metres: } \\
10000 \text { ha }\end{array}$ \\
\hline Description of the location & $\begin{array}{l}\text { information about the location and terrain, human activity: } \\
\text { The monitoring location consists of forests within the Danum Valley Conser- } \\
\text { vation Area }\end{array}$ \\
\hline $\begin{array}{l}\text { Informations about the } \\
\text { habitat in location }\end{array}$ & $\begin{array}{l}\text { description of the species habitat in location: } \\
\text { The habitat of lesser mouse-deer in Danum Valley Conservation Area is a } \\
\text { primary rainforest. There is no anthropogenic activity in this region, except for } \\
\text { few roads and tourist bases. The Segama River flows through the monitored } \\
\text { area, the highest point of the location is the Gunung Danum peak, } 1093 \mathrm{~m} \\
\text { a.s.l. }\end{array}$ \\
\hline $\begin{array}{l}\text { Informations about the } \\
\text { species in location }\end{array}$ & $\begin{array}{l}\text { brief information about the species occurrence in location, previous research } \\
\text { and other relevant facts, results of previous studies: } \\
\text { The species has not yet been studied in the location, so there is no additional } \\
\text { information about it }\end{array}$ \\
\hline Is monitoring required? & $\begin{array}{l}\text { yes/no, if „no”, then justification is required: } \\
\text { Yes. The population is stable, however it is susceptible to rapid changes in } \\
\text { numbers and relatively small. Continuation of monitoring will make it possible } \\
\text { to assess the factors responsible for the presence of the species in studied } \\
\text { area, which in turn will aid in verification of the existing indicators, together with } \\
\text { assessment and the determination of new factors necessary for evaluation of } \\
\text { the conservation status of the species' habitat }\end{array}$ \\
\hline
\end{tabular}

Table 5. Habitat observation sheet - current factors impacting the population

Current impacts

\begin{tabular}{lccl}
\hline Name of activity & intensity & impact & brief description \\
\hline Reforestation & $\mathrm{B}$ & $+\begin{array}{l}\text { actions aimed at afforestation of previously } \\
\text { felled areas }\end{array}$ \\
\hline Roads, highways & $\mathrm{B}$ & $-\begin{array}{l}\text { forest roads crossing the area, leading to tourist } \\
\text { bases }\end{array}$ \\
\hline Path, hiking trails & $\mathrm{C}$ & - & tourist routes and educational paths \\
\hline Poaching & $\mathrm{B}$ & - & illegal hunting of animals \\
\hline Educational centres & $\mathrm{C}$ & - & turist bases in the area \\
\hline Predation & $\mathrm{B}$ & - & predation pressure from native species \\
\hline $\begin{array}{l}\text { Antagonistic relationship with domestic } \\
\text { animals }\end{array}$ & $\mathrm{B}$ & - & attacks by stray dogs \\
\hline
\end{tabular}

A - strong, $\mathrm{B}$ - moderate, $\mathrm{C}$ - weak.

"-" - negative, , ," - positive, ,0" - neutral. 
Table 6. Habitat observation sheet - predicted threats, that can impact the population

\begin{tabular}{lccl}
\hline & \multicolumn{2}{c}{ Threats (future, anticipated impacts) } \\
\hline Name of activity & itensity & impact & brief description \\
\hline $\begin{array}{l}\text { Improperly implemented } \\
\begin{array}{l}\text { conservation measures } \\
\text { or lack of such measures }\end{array}\end{array}$ & A & - & $\begin{array}{l}\text { lack of actions aiming at maintaining } \\
\text { the population in good condition }\end{array}$ \\
\hline Poaching & B & - & illegal hunting of animals \\
\hline $\begin{array}{l}\text { Predation } \\
\begin{array}{l}\text { Antagonistic relationship } \\
\text { with domestic animals }\end{array}\end{array}$ & B & - & predation pressure from native species \\
\hline
\end{tabular}

A - strong, B - moderate, C - weak.

"-" - negative, , $+"$ - positive, ,0" - neutral.

Table 7. Habitat observation sheet - species conservation status (assigned exemplary grades FV, U1 and $\mathrm{U} 2$ are marked as bold and underlined)

\begin{tabular}{|c|c|c|c|c|}
\hline \multicolumn{5}{|c|}{ Species conservation status in monitoring location } \\
\hline Parameter & measures & evaluation and comments & & nent \\
\hline \multirow{2}{*}{ Population } & $\begin{array}{l}\text { population } \\
\text { density }\end{array}$ & $\begin{array}{l}\text { mean density }-22 \\
\text { specimens } / \mathrm{km}^{2}\end{array}$ & & \multirow{2}{*}{$\underline{\mathrm{FV}} / \mathrm{U} 1 / \mathrm{U} 2 / \mathrm{XX}$} \\
\hline & reproduction & few mothers with young & $\mathrm{FV} / \underline{\mathrm{U} 1 / \mathrm{U} 2 / \mathrm{XX}}$ & \\
\hline \multirow[b]{2}{*}{ Habitat } & type of habitat & $\begin{array}{l}\text { primary forest (lack of } \\
\text { significant human impact) }\end{array}$ & $\underline{\mathrm{FV}} / \mathrm{U} 1 / \mathrm{U} 2 / \mathrm{XX}$ & \multirow[b]{2}{*}{$\underline{\mathrm{FV}} / \mathrm{U} 1 / \mathrm{U} 2 / \mathrm{XX}$} \\
\hline & $\begin{array}{l}\text { presence of fruit } \\
\text { tree / shrubs } \\
\text { and fallen fruit }\end{array}$ & $\begin{array}{l}\text { numerous fruit trees / shrubs } \\
\text { and fallen fruit }\end{array}$ & $\underline{\mathrm{FV}} / \mathrm{U} 1 / \mathrm{U} 2 / \mathrm{XX}$ & \\
\hline $\begin{array}{l}\text { Perspectives of } \\
\text { conservation }\end{array}$ & \multicolumn{2}{|c|}{$\begin{array}{l}\text { perspectives are good, the numer of animals } \\
\text { seems to stay at sufficiently high level, } \\
\text { population is not isolated, reproduction was } \\
\text { observed, the habitat is not degraded }\end{array}$} & \multicolumn{2}{|c|}{$\underline{\mathrm{FV}} / \mathrm{U} 1 / \mathrm{U} 2 / \mathrm{XX}$} \\
\hline Final assessment & & & \multicolumn{2}{|c|}{$\mathrm{FV} / \underline{\mathrm{U} 1 / U 2 / X X}$} \\
\hline
\end{tabular}

FV - appropriate, U1 - unsatisfactory, U2 - bad, XX - unknown.

Table 8. Habitat observation sheet - other information

\begin{tabular}{ll}
\hline \multicolumn{1}{c}{ Other information } \\
\hline Other natural values & $\begin{array}{l}\text { other endangered species (population size described as: numerous, moderately } \\
\text { numerous, rare); other unique natural values: } \\
\text { Sus barbatus, Müller, } 1838 \text { - moderately numerous; Buceros rhinoceros, } \\
\text { Linnaeus, 1758 - rare }\end{array}$ \\
\hline $\begin{array}{l}\text { Alien and invasive } \\
\text { species }\end{array}$ & $\begin{array}{l}\text { observed alien and invasive species; if possible with their population size } \\
\text { Not observed }\end{array}$ \\
\hline Methodological notes & $\begin{array}{l}\text { information necessary for further planning of monitoring studies (way of con- } \\
\text { ducting studies, indicators, that should be studies and evaluated, optimal research } \\
\text { time e.t.c.): } \\
\text { None }\end{array}$ \\
\hline $\begin{array}{l}\text { Ony additional information that may aid in interpreting the results, e.x. about } \\
\text { weather conditions: } \\
\text { None }\end{array}$ & $\begin{array}{l}\text { attachment for the database (in electronic version): a minimum of the photographs } \\
\text { per monitoring location (species, habitat, borders of studied area marked } \\
\text { on a map) }\end{array}$ \\
\hline $\begin{array}{l}\text { Photographic and } \\
\text { cartographic } \\
\text { documentation }\end{array}$ &
\end{tabular}




\section{SPECIES OF SIMILAR ECOLOGICAL REQUIREMENTS FOR WHICH THE SUGGESTED METHODOLOGY CAN BE ADAPTED}

The methodology of lesser mouse-deer monitoring has been developed in such a way, that it may be combined with monitoring of species such as Java mouse-deer Tragulus javanicus, Osbeck, 1765, Vietnam mouse-deer Tragulus versicolor, Thomas, 1910, Philippine mouse-deer Tragulus nigricans, Thomas, 1892, greater mouse-deer Tragulus napu, Cuvier, 1822 and Williamson's mouse-deer Tragulus williamsoni, Kloss, 1916. Monitoring locations, research points, methodology of conducting studies (length of the transects at designated monitoring areas), as well as time and frequency of studies overlap or are similar for each of these species.

\section{PROTECTION OF THE SPECIES}

At the moment, it does not seem necessary to carry out intensive protective measures for the lesser mouse-deer, however no species-specific estimates of population size has been made and current population trend is unknown (Timmins and Duckworth 2015). Nevertheless, establishing areas of protected natural habitat is certainly beneficial for the species, together with lack of intensive investment activities or deforestation in the areas inhabited by the species.

The most factor threatening the population is deforestation and environmental degradation associated with it (Matsubayashi 2005). Moreover, isolation of the population caused by e.g. building roads may have a detrimental impact, as it hinders the mating of unrelated individuals and reduces genetic diversity. Developing tourist infrastructure is also a threat, as increased human activity in areas inhabited by kanchils may disturb the animals and have a detrimental impact on the quality of the habitat. Another major concern is poaching and vandalism. Also increased predation pressure, caused partially by attacks of domestic species, such as stray dogs, might threaten the population.

General recommendation consist of regular inspections at the locations occupied by the lesser mouse-deer. Reliably performed monitoring is crucial, together with active protective measures aiming at immediate reaction to possible sudden adverse changes in the number or structure of the population.

\section{CONCLUSIONS}

At the current state of research lesser mouse-deer is still considered data deficient by science in regions it inhabits. The fact, that there were no known attempts of estimating the population size suggests, that such studies should be given a priority. Determining the size of the population will make it possible to establish the most accurate methods of monitoring in the future. Further studies should also focus on evaluating current and possible threats and factors impacting the population. Regular monitoring of the population, carried out in a credible way, will allow appropriate conservation activities to be applied when needed. 


\section{REFERENCES}

Grzimek T. 2003. Grzimek's animal life encyclopedia, vol. 15, Farmington Hills, Gale Group.

Heydon M.J., Bulloh P. 1997. Mousedeer Densities in a Tropical Rainforest: The Impact of Selective Logging. J. App. Ecol. 34(2), 484-496.

Jinaka H. 1995. Endangered animal - mouse deer. A guide to the threatened animals of Singapore, vol. 2, 38-39.

Matsubayashi H. 2005. Activity and habitat use of two sympatric mouse-deer species, Tragulus javanicus and Tragulus napu, in Sabah, Borneo. Malayan Nat. J. 57(2), 235-241.

Nowak R.M., Paradiso J.L. 1983. Walker's mammals of the world, vol. 2, 4th ed., Baltimore, The Johns Hopkins University Press.

Payne J., Francis C.M., Phillipps K. 1985. A field guide to the mammals of Borneo, Kota Kinabalu Kuala Lumpur, The Sabah Society and WWF Malaysia.

Timmins R., Duckworth J.W. 2015. Tragulus kanchil: The IUCN Red List of Threatened Species 2015.

\section{PROPOZYCJA MONITORINGU KANCZYLA ORIENTALNEGO Tragulus kanchil}

Streszczenie. Kanczyl orientalny Tragulus kanchil Raffles, 1821 jest niewielkim roślinożernym ssakiem, zamieszkującym tereny południowo-wschodniej Azji. W przeciwieństwie do innych krytycznie zagrożonych gatunków, należących do tej samej rodziny, kanczyl orientalny występuje stosunkowo powszechnie. Jednak biologia gatunku, a także wielkość jego populacji są wciąż słabo poznane. Dotychczas nie zostały opracowane metody monitoringu dotyczące tego gatunku. Z tego względu w pracy zaproponowany został przykładowy sposób prowadzenia badań monitoringowych kanczyla orientalnego. Głównym celem badań jest oszacowanie liczebności populacji gatunku, jak również ocena jakości zajmowanych przez niego siedlisk. $\mathrm{Na}$ potrzeby przeprowadzenia takiej oceny zaproponowano wskaźniki dotyczące populacji i siedliska. Metodologia badań jest głównie oparta na zliczaniu osobników na wyznaczonych transektach, jak również na ocenie jakości siedliska i dostępności bazy pokarmowej. Zaproponowane zostały również metody dodatkowe, takie jak badania genetyczne i wykorzystanie fotopułapek. Badania tego typu mogą dostarczyć cennych informacji dotyczących wymagań siedliskowych kanczyla orientalnego, jak również danych o potencjalnych zagrożeniach mogących mieć wpływ na populację. W przyszłości zaproponowane metody mogłyby zostać rozszerzone lub udoskonalone, aby w jak najbardziej kompleksowy sposób dostarczyć wiadomości dotyczących gatunku, a także wspomóc opracowywanie i wdrażanie niezbędnych działań ochronnych.

Słowa kluczowe: kanczyl orientalny, Tragulus kanchil monitoring, ochrona. 
